\title{
The Right to Education of Persons in Detention: Summary of Report Presented to the UN Human Rights Committee in June 2009 Vernor Muñoz
}

$\mathrm{I}^{1}$

n 1998, the United Nations established the mandate of the "Special Rapporteur on the Right to Education". A Special Rapporteur is an independent expert appointed by a body of the United Nations, the Human Rights Council, to examine and report back on a country situation or a specific human rights theme. I was appointed Special Rapporteur in 2004 and although I recognized that numerous children and adults alike are denied their right to education generally, I felt it appropriate to focus attention on groups traditionally marginalized and vulnerable to discrimination. I have sought to establish the causes and circumstances surrounding such discrimination and the challenges that must be faced in order to promote the realization of their right to education. Persons in detention constitute one such highly marginalized group, facing daily, sustained and endemic violations of that right. This article offers a brief summary of the recent report titled "The right to education of persons in detention" presented to the Human Rights Council in June 2009. It may be found in full at:

http://www2.ohchr.org/english/bodies/hrcouncil/11session/reports.htm

It was particularly important to hear and understand the views and experiences of prisoners themselves. Their willingness to share these has been invaluable and, as noted below, their views should be sought as a matter of course in deciding penal education policy and its implementation.

\section{Background to Education in Detention}

The provision of education for persons in detention is inherently complex and, where it does take place, it does so in an environment inherently hostile to its liberating potential (Scarfó, 2008). Frequently inadequate attention and resources - human and financial - dedicated to adequate education, combined with the damaging impact of detention, exacerbate often low levels of self-esteem and motivation of learners, creating major challenges for prison administrators, staff and learners alike.

Nonetheless, there is a growing recognition of the benefits of education as a vital element in addressing the ability of prisoners to develop and 
maintain skill sets that will enable them to take advantage of social, economical, and cultural opportunities. While this recognition is welcome and necessary, it should be noted that the nature, provision, quality, and participation rates of education in detention vary significantly between and within regions, States, and even individual institutions. While this variation in education too often tends to oscillate between the 'poor' and 'very poor', full acknowledgment must be made of the number of educational programs of exceptional quality which, from prisoners' own observations, are the result of individual initiative and extraordinary commitment, rather than necessarily the product of State or individual institutional policy. ${ }^{1}$

\section{Conflicting Philosophies and Assumptions: Role of Prisons vs. 'Correctional' Education vs. The Right to Eduction}

The role of education within places of detention must be examined against the broader objectives of penal systems, which are inherently institutions of coercion, serving a set of complex and mutually conflicting objectives. They reflect to differing degrees prevailing societal calls for punishment, deterrence, retribution and/or rehabilitation, as well as a managerial focus on resource management and security.

Opportunities for education should be commonplace in detention (Morin and Cosman, 1989), not simply an add-on should resources 'allow' it. It should be aimed at the full development of the whole person requiring, amongst others, prisoner access to formal and informal education, to literacy programmes, basic education, vocational training, creative, religious and cultural activities, physical education and sport, social education, higher education and library facilities. ${ }^{2}$ Prisoners should have a say in how these opportunities for education are designed. Respect for the human dignity of all within the community - whether in detention or not - presupposes genuine participation in decisions impacting our lives, including those relating to educational provision.

\section{International Legal and Political Developments}

Criminal justice issues are principally the concern of domestic policy and legislation that reflect their historical and cultural context. Nonetheless, 
there has been a long standing concern of the international community about the humanization of criminal justice, the protection of human rights, and the importance of education in the development of the individual and the community. ${ }^{3}$ This, combined with the acknowledged particular vulnerability of those in detention to State action and its consequences, has led to the development of international standards that aim to confront the challenges of stigma, indifference and marginalization that so often characterize education in detention.

Unlike many other 'groups' that endure discrimination, people in detention do not benefit from a dedicated legally binding text. In 1990, however, the General Assembly usefully synthesized the basic principles for the treatment of prisoners. In particular, it noted that:

- All prisoners shall be treated with the respect due to their inherent dignity and value as human beings, ${ }^{4}$

- Except for those limitations that are demonstrably necessitated by the fact of incarceration, all prisoners shall retain the human rights and fundamental freedoms set out in the Universal Declaration of Human Rights, and where the State concerned is a party, the International Covenant on Economic, Social and Cultural Rights (ICESCR), and the International Covenant on Civil and Political Rights (ICCPR) and the Optional Protocol thereto, as well as such other rights as are set out in other United Nations covenants; ${ }^{5}$ and

- All prisoners shall have the right to take part in cultural activities and education aimed at the full development of the human personality. ${ }^{6}$

There are many other international instruments that deal specifically with prisons and conditions of detention and offer guidance for good prison management ${ }^{7}$ but other than the 1990 General Assembly resolution noted above, perhaps the most prominent for the purposes of this report are the Standard Minimum Rules for The Treatment of Prisoners (1957) and the Standard Minimum Rules for the Administration of Juvenile Justice (1985). Both insist upon the provision by States of a wide reaching education for those they have sought to detain.

The development of binding international law and guidance pertaining to education in detention is of course welcome and helps inform the international debate about the treatment of prisoners, especially in their 
access to education. Even though States have had the pre-eminent role in setting these standards however, full compliance remains poor and until the international community fully endorses the underlying principles, these standards will continue to have limited impact.

The right to education is now generally accepted as encompassing the provision of an education that is, at the very least, available, accessible, adaptable and acceptable. ${ }^{8}$ No text allows for forfeiture of this right and, more essentially, forfeiture is not necessitated by the fact of incarceration.

\section{The Reality of Prison Education}

\section{Global Detention: Levels and Trends}

Existing data suggests that over 9.25 million people are detained globally, either as pre-trial detainees or as sentenced prisoners. Almost half of these are in the U.S. $(2.19 \mathrm{~m})$, China $(1.55 \mathrm{~m})$ or Russia $(0.87 \mathrm{~m}){ }^{9}$ Prison populations are increasing in an estimated $73 \%$ of States,${ }^{10}$ a figure mirrored in overcrowding which has reached, for example, $374.5 \%$ of capacity in Grenada, 330\% in Zambia and 108\% in the U.S. ${ }^{11}$

\section{General Barriers to Education in Detention}

Public opinion, often indifferent to and ignorant of detention can sometimes be perceived as the main barrier in fulfilling the potential of education in prison although the main responsibility rests on the State through its public policies of education. These attitudes are fuelled by an often equally illinformed and ill-advised media which, when reporting on criminal justice 'stories', focuses almost exclusively on unrepresentative individual violent events. The too ready willingness of politicians to reflect these fears in penal policy has led to a reluctance to embed prisoners' right to education in legislation, and to develop models of education and delivery consistent with the full development of the human personality. Within this context, and while recognizing that each person is unique in their learning needs and experiences, barriers to education in relevant literature are often broken down into three categories: dispositional, institutional and situational. ${ }^{12}$

Barriers external to the learner, institutional and situational in detention, are perhaps best detailed by learners themselves. Their list is long, globally relevant and includes: troubling examples of education interrupted or 
terminated on the personal whims of prison administrators and officers, and by frequent lockdowns and abrupt transfers between institutions; the absence of libraries; the absence and confiscation of written and educational material generally; waiting lists of up to three years for courses; limited, and often complete absence of, access to and training in IT and related skills necessary in today's IT-driven community and specifically linked to this, of a perceived focus on education linked to prison management rather than the specific needs and rights of prisoners.

Staff shortages lead to cancelled or untenable mixed ability classes and absence of staff to invigilate exams; of poor timetabling; of inconsistent and poor quality tuition; of too basic, irrelevant and/or inappropriate curriculums; of vocational courses which are dated paths to nowhere; of teaching skills that are no longer in demand; of absence of safe and stable spaces in which to learn; indifference to needs associated with specific disabilities; of withdrawal of educational 'privileges' as a punitive measure; of the absence and/or withdrawal of public funding for, particularly, higher education along with the prohibitive costs of self funding; of financial 'penalties' incurred if education is pursued in place of prison employment; of discriminatory access to education based on place of detention, sentence length, and/or security category; and as will be detailed below, discriminatory, inappropriate and inadequate education for women, minorities and those with learning difficulties. ${ }^{13}$

\section{The Experience of Specific Groups in Detention}

Whilst recognizing the real risk of 'grouping' people, one reason being that no group is homogenous, certain people do appear to experience similarities in their educational needs and experiences. Foreign nationals may, for instance, have no command of the language of instruction and/or persons with learning disabilities who face stigma and discrimination generally, and in education specifically, ${ }^{14}$ are frequently made yet more vulnerable by penal systems that invariably fail to recognize, understand or support their specific needs.

Children, including juveniles, who constitute a particularly vulnerable group also as perpetrators of crimes, ${ }^{15}$ often find themselves in justice systems with few guarantees of access to education, and even where provided, are in receipt of one that is not adaptable, is inadequate and illsuited to their needs. 
Women represent a small proportion of the global prison population worldwide. Available figures suggest the rates, which are now increasing, to be between two and nine percent ${ }^{16}$ with the global average standing at roughly four percent (Walklate, 2001). In many States where educational attainment is assessed upon entry, it is often not assessed by sex. Nonetheless, where figures do exist it would appear that women have lower levels of educational attainment than men, reflecting pervasive gender discrimination generally. In many States there are fewer and lesser-quality programs offered to women compared to those offered to male detainees. ${ }^{17}$

\section{Engagement of States in Preparation of Report}

In early October 2008 a questionnaire was sent to all Member States of the UN, along with a number of intergovernmental and non-governmental organizations working on issues related to the right to education and education in the context of detention.

\section{State Responses}

As State responses to the questionnaire differed markedly in detail and transparency, comparisons were difficult to assess with confidence. Nonetheless, a number of notable themes are apparent, the first of which is a general acknowledgment that the right to education enshrined in Constitutions or legislation applies equally to persons in detention, although this is not explicitly guaranteed.

While most States indicate that education is one of the main components of their criminal justice management strategy, almost all emphasized its role in employment, rehabilitation and reintegration upon release. These are of course vital objectives but the frequent focus on employment prospects remains somewhat narrower than that required by the right to education.

The imperative of security is the principal reason given for restricting access to education and the frequent limited access to computers and/or the internet. More specifically limited access to computers does of course impact upon the relevance of educational provision in this technological age, and in turn impacts upon the increased significance of well stocked, accessible and relevant libraries. Most, but not all, prisons do have libraries of some form, although it is clear that some rely to differing extents on the efforts of NGOs in their sourcing, financing and maintenance. 
In the majority of responding States, education is offered free of charge to the detainee, at least with regards to primary, secondary (where provided), as well as vocational training. The cost of higher education where offered whether by distance learning or personal attendance is more usually borne by the detainee and/or financed by private grants.

Participation of diverse actors, such as detainees, prison officers, the outside community, NGOs and families in the design, delivery, and monitoring of educational programmes is known to impact positively on their relevance and outcome. Despite this a number of States make no formal provision for participation of detainees or others directly impacted.

Although most States acknowledge the diverse background and needs of persons in detention, they offer little indication of how this diversity is reflected in programmes and curriculum offered, other than for instance referring to the provision of special language classes for non-nationals.

It is clear that a number of States are at the early stage of developing a coherent policy for education in detention, others are midway through, while others build upon past efforts. State replies to the questionnaire do not generally leave the impression that this is currently the case despite, with regard to best practice in particular, receipt of information concerning a number of very interesting and innovative programs from States, individuals, and organizations alike.

\section{Replies by Intergovernmental Organizations, NGOs and Civil Society}

Without the active involvement of dedicated individuals, academic institutions and NGOs, education in detention would be far poorer than is currently the case or, in some institutions, even non-existent. They are all well placed to contribute to the quality and relevance of the global debate on education for even where they do not actively provide educational services themselves, they see and/or specifically experience the practical day-to-day realities of life in detention, as well as legislative and policy implications, together with their long-term consequences.

The responses represent a wide geographical spread and provide independent comment on the provision of education for those in detention in specific States, filling some of the gaps in information provided by States themselves. Further they offer a very different perspective to that of States, often highlighting consistent patterns of denial of the right to education, details of which have been incorporated in the text above. Their credible and 
important perspective clearly suggests the need for States to involve such organizations/individuals closely in legislative and policy developments, along with their practical implementation.

\section{Conclusion and Recommendations}

Persons deprived of their liberty remain entitled to their inherent human rights - including their right to education. The challenge before us is to create an environment for those who are detained that enables human dignity, capacity and positive change. The provision of accessible, available, adaptable and acceptable education is one vital element in this environment. The principle obligation to provide this education is upon States. Nonetheless we must come together with the shared aim of fulfilling the right to education for persons in detention to a far greater extent than now seems to be the case.

1. To this end I direct the following recommendations to States:

(a) Education for persons in detention should be guaranteed and entrenched in Constitutional and/or other legislative instruments;

(b) The provision of education for persons in detention should be adequately resourced from public funds; and

(c) Compliance in the standards set forth in international law and guidance pertaining to education in detention should be ensured.

2. To domestic authorities in charge of public education I recommend that they should:

(a) Make available to all detainees, whether sentenced or in remand, educational programmes that would cover at least the curriculum of compulsory education at the primary and if possible, also at the secondary level;

(b) Together with the institutions of detention, arrange comprehensive education programmes aimed at the development of the full potential of each detainee. These should aim also to minimize the negative impact of incarceration, improve prospects of reintegration, rehabilitation, self esteem and morale; 
(c) Systematic and appropriate screening of all prisoners upon entry to places of detention should become the norm. Individual educational plans with full participation of the detainee, should result from this screening, and be monitored, evaluated and updated from entry to release;

(d) States should identify the dispositional barriers to education, and subsequently ensure adequate assistance and resources to meet their challenge;

(e) Education programmes should be integrated with the public system so as to allow for continuation of education upon release;

(f) Detention institutions should maintain well funded and accessible libraries, stocked with an adequate and appropriate range of resources, including technological, available for all categories of detainees;

(g) Teachers in places of detention should be offered approved training and ongoing professional development, a safe working environment, and appropriate recognition in terms of working conditions and remuneration;

(h) Evaluation and monitoring of all education programs in detention should become the norm and a responsibility of Ministries of Education. States are encouraged to investigate which practices pervade their prison estates, to recognize them and take prompt steps to address them;

(i) Educational programs in detention should be adequately based on current, multidisciplinary and detailed research. To this end the international community should establish cooperation and exchange mechanisms between States to facilitate the sharing of such research, and examples of best practice and their implementation;

(j) The diverse background and needs of persons in detention indication, and how this diversity is reflected in programmes and curriculum offered is also an area where the sharing of research, best practice and experience would generate particular dividends, and is therefore specifically and strongly encouraged; and

(k) The production and delivery of adequate pedagogical material with the necessary and active participation of all persons in 
detention, and more specifically those from marginalized groups, should also be encouraged.

3. In specific respect of children and women in detention and other marginalized groups:

(a) Special attention must be given to ensuring that all children subject to compulsory education have access to, and participate in, such education;

(b) Curricula and educative practices in places of detention must be gender sensitive, in order to fulfill the right to education of women and girls; and

(c) Attention should be also given to persons from traditionally marginalized groups including women, minority and indigenous groups, those of foreign origin, and persons with physical, learning and psychosocial disabilities. Education programs for such groups should pay close attention to accessibility and relevance to individual needs, and the barriers to continued education upon release should be addressed and properly taken care of.

Deprivation of liberty should be a measure of last resort. Given the considerable negative long-term economic, social and psychological consequences of detention on detainees, their families and the community, considerably greater attention should be paid to implementing alternatives to detention for children and adults alike.

\section{ENDNOTES}

Contributions from detainees. Letters on file with the author.

Article 3 (b) ECOSOC Resolution, E/1990/69.

Ibid.

Article 1 Basic Principles for the Treatment of Prisoners: Adopted and Proclaimed by General Assembly resolution 45/111 of 14 December 1990.

5 Ibid, Article 5. The right to education forms a core element to instruments specified and many 'other' UN covenants.

Ibid, Article 6.

7 See also for instance the publication of the United Nations, Human Rights and Prisons - a training package for prison officials, available at www.ohchr.org.

8 See E/CN. 4/1999/49 and General Comment 13, Committee on Economic, Social and Cultural Rights, The right to education, E/C.12/1999/10. 
9 The USA also leads the tables in the proportion of its population it detains; 738 per 100,000 followed closely by Russia at 611 per 100,000; see R. Walmsley, World Prison Population List (seventh edition), London: International Centre for Prison Studies - Kings College London.

10 Ibid.

11 World Prison Brief, London: International Centre for Prison Studies, Kings College London.

12 Scurrah, M., Learning on the Inside in Risdon Prison, unpublished report on file with author.

13 Information provided by prisoners and former prisoners: on file with author.

14 See the report on the right to education of persons with disabilities, A/HRC/4/29 (2007).

15 Carranza, E. (2004) Criminalidad, Políticas Públicas y Edad de ingreso a la Responsabilidad penal. Read at Congreso de Salamanca available at: http://wwwoijj. org.

16 Walmsley, R., World Female Imprisonment List 2006, International Centre for Prison Studies, www.prisonstudies.org.

17 Fundacion Somos Familia (2008) Aula de Derechos Humanos, Cuenca Ecuador. See also Farrell, A., S. Danby, P. Skoien and C. Quadrelli (2000) "Women Inmates' Accounts of Education In Queensland Corrections", Australia and New Zealand Journal of Law and Education, 6(1\&2): 47-61.

\section{REFERENCES}

Morin, Lucien and J.W. Cosman (1989) "Prison Education: The Need for a Declaration of Basic Principles for the Treatment of Prisoners", The Yearbook of Correctional Education: 83-99.

Scarfó, Francisco (2008) Indicadores sobre las condiciones de realización del derecho a la educación en las cárceles, Facultad de Ciencias Jurídicas y Sociales, Argentina: Universidad Nacional de La Plata.

Walklate, Sandra (2001) Gender, Crime and Criminal Justice, Cullompton: Willam. 